\title{
Converting mesquite thickets to savanna through foliage modification with clopyralid
}

\author{
R. J. ANSLEY, B.A. KRAMP, AND D.L. JONES
}

Authors are Associate Professor (r-ansley@tamu.edu), Research Associate and Research Technician, Texas Agricultural Experiment Station, Vernon, Tex.

\section{Abstract}

Honey mesquite (Prosopis glandulosa Torr.) is a problem plant in much of the southwestern USA because it reduces forage production for livestock, interferes with livestock handling and reduces off-site water yield. Aerial spraying a 1:1 mixture of clopyralid (3,6-dichloro-2-pyridinecarboxylic acid, monoethanolamine salt) and triclopyr (3,5,6-trichloro-2-pyridinyloxyacetic acid, butyoxyethyl ester) at $0.28 \mathrm{~kg} \mathrm{ae} \mathrm{ha}^{-1}+0.28 \mathrm{~kg}^{-1 e} \mathrm{ha}^{-1}$ usually achieves high above-ground (top-kill) and whole plant (root-kill) mortality, but limits multiple-use options of livestock and wildlife production because little mesquite foliage is left to provide screening cover for wildlife. In addition, most surviving plants resprout from basal meristems and will become multistemmed plants. Some managers treat mesquite in strips or blocks, leaving untreated areas for screening cover, but these areas become increasingly non-productive for livestock and wildlife forage. The objective of this study was to evaluate the potential of aerial sprays of clopyralid alone at $0.28 \mathrm{~kg} \mathrm{ha}^{-1}$ to convert thickets of mature, multi-stemmed mesquite to savannas by reducing mesquite foliage amount to an intermediate level (by 50-70\%), yet preserving apical dominance and limiting basal sprouting. The clopyralid treatment was compared to an untreated control and aerial sprays of $0.28 \mathrm{~kg} \mathrm{ha}^{-1}$ clopyralid $+0.28 \mathrm{~kg}$ $\mathrm{ha}^{-1}$ triclopyr on 2 sites. The clopyralid treatment reduced foliage amount tree $e^{-1}$, canopy area tree $e^{-1}$, and stand-level mesquite cover by $>57 \%$ when compared untreated areas, and $73 \%$ of surviving trees maintained apical dominance. Apical dominance was maintained in $>70 \%$ of trees not totally top-killed if at least $20 \%$ of the original canopy survived and produced foliage following the spray year. Percent root-kill in the clopyralid-only treatment differed between sites ( 34 and $10 \%)$. The lower root-kill on one site was attributed to rainfall that occurred 2 days before and one day after spraying. The clopyralid+triclopyr treatment reduced foliage on original canopies by $>96 \%$ and mesquite cover by $82 \%$ on both sites. Root-kill was $>52 \%$ on both sites but only $37 \%$ of surviving plants maintained apical dominance. Results suggest that clopyralid at $0.28 \mathrm{~kg} \mathrm{ha}^{-1}$ may be effective for converting mesquite thickets to savanna and may aid in multiple-use management.

Key Words: Brush management, brush sculpting, canopy cover, multiple use, Prosopis glandulosa, shrubs, triclopyr, woody plants

Research was funded by grants from the E. Paul and Helen Buck Waggoner Foundation, Vernon, Tex, Dow AgroSciences, Indianapolis, Ind. and the University Lands-Surface Interests, University of Texas System, Midland. We thank the W.T. Waggoner Ranch and the C.C. Burgess Y Ranch for providing research sites for this project. Gerral Schulz, Tim Tunnell and Matt Angerer assisted with herbicide application and data collection. We appreciate the assistance of Hardcastle Ag-Air Vernon, who provided aircraft to apply the treatments Don Robinson, Richard

Teague, Bill Pinchak, and Wylie Harris reviewed earlier drafts of the manuscript.

Manuscript accepted 7 May 02.

\section{Resumen}

El "Mezquite" (Prosopis glandulosa Torr.) es una planta problema en gran parte del sudoeste de Estados Unidos porque reduce la producción de forraje para el ganado, interfiere con el manejo del mismo y reduce los rendimientos de agua del sitio. La aspersión aérea de una mezcla en proporción 1:1 de clopiralid (ácido 3,6-dicloro-2-piridinecarboxilico,sal monoetanolamina) y triclopir (ácido 3,5,6-tricloro-2-piridiniloxiacético, butioxietil ester) en dosis de $0.28 \mathrm{~kg}$ i.a. ha $^{-1}+0.28 \mathrm{~kg}$ i.a. ha $^{-1}$ usualmente logra una alta mortalidad de la parte aérea y mortalidad total (muerte de raíz)de la planta, pero limita las opciones de uso múltiple de ganado y producción de fauna porque queda poco follaje de "Mezquite"para proveer una cubierta de protección para la fauna. Además, la mayoría de las plantas sobreviventes rebrotan de meristemos basales creando plantas multi-tallos. Algunos manejadores tratan el mezquite en franjas o bloques, dejando áreas sin tratar para tener una cubierta de protección, pero estas áreas poco a poco llegan a ser improductivas de forraje tanto para el ganado como para la fauna. El objetivo de este estudio fue evaluar el potencial de aspersiones aéreas de clopiralid solo en dosis de $0.28 \mathrm{~kg} \mathrm{ha}^{-1}$ para convertir poblaciones densas de plantas de "Mezquite" maduras multi-tallos en savanas reduciendo la cantidad de follaje a un nivel intermedio $(50-70 \%)$, pero preservando la dominancia apical y limitando el rebrote basal. El tratamiento de clopiralid se comparó con un control sin tratar y con aspersiones aéreas de $0.28 \mathrm{~kg} \mathrm{ha}^{-1}$ clopiralid $+0.28 \mathrm{~kg} \mathrm{ha}^{-1}$ triclopir, la comparación se efectuó en 2 sitios. El tratamiento de clopiralid redujo la cantidad de follaje árbol-1, el área de copa árbol ${ }^{-1}$ y el nivel de cobertura de la población de mezquite en $>57 \%$ en comparación con las áreas sin tratar y $73 \%$ de los árboles sobrevivientes mantuvieron la dominancia apical. La dominancia apical se mantuvo en mas del $70 \%$ de los árboles en los que la parte aérea no se murió totalmente y que al menos $20 \%$ de la copa original sobrevivió y produjo follaje en el año siguiente de la aplicación. El porcentaje de árboles muertos de raíz en el tratamiento de clopiralid solo difirió entre sitios ( 34 y 10\%). El porcentaje mas bajo de muerte de raíz en uno de los sitios se atribuyó a la lluvia que ocurrió 2 días antes y uno después de la aplicación. El tratamiento de clopiralid + triclopir redujo el follaje de la copa original en mas del $96 \%$ y la cobertura de mezquite en $82 \%$, la respuesta fue similar en ambos sitios. La muerte de raíz fue mas de $52 \%$ en ambos sitios, pero solo el $37 \%$ de las plantas sobrevivientes mantuvieron la dominancia apical. Los resultados siguieren que el clopiralid en dosis de $0.28 \mathrm{~kg} \mathrm{ha}^{-1}$ pueden ser efectivos para convertir las áreas con invasiones densas de "Mezquites" en savanas y puede ayudar en el manejo de uso múltiple. 
Honey mesquite (Prosopis glandulosa Torr.) is considered a problem plant in much of the southwestern USA because it reduces forage production for livestock, interferes with livestock handling and reduces off-site water yield (Dahl et al. 1978, Bedunah and Sosebee 1984, Teague et al. 1997). Treatments that only top-kill mesquite, such as chaining, shredding, high-intensity fires, or herbicides such as triclopyr (3,5,6-trichloro-2-pyridinyloxyacetic acid, butyoxyethyl ester), compound the problem by stimulating regrowth from stem bases, thus increasing stem numbers and the competitive effects of mesquite (Fisher et al. 1959, Scifres et al. 1974, Jacoby and Ansley 1991, Ansley and Jacoby 1998).

A widely used aerial herbicide treatment for mesquite control is a 1:1 mixture of clopyralid (3,6-dichloro-2-pyridinecarboxylic acid, monoethanolamine salt) and triclopyr applied at $0.28 \mathrm{~kg}$ ae ha- +0.28 $\mathrm{kg}$ ae $\mathrm{ha}^{-1}$. This treatment achieves high levels of top-kill and root-kill (Bovey and Meyer 1985, Bovey and Whisenant 1991, 1992), although most surviving mesquite have basal regrowth and will become multi-stemmed trees. While viewed as a "best management option" by many livestock producers, this treatment initially leaves so little mesquite foliage remaining that live-tree screening cover for many wildlife species is inadequate. To achieve multiple-use goals of livestock and wildlife production, patterned spraying or mechanical treatments are often employed that leave alternating treated and untreated strips or blocks (Scifres et al. 1985, Scifres and Koerth 1986, Fulbright 1996, 1997, Rollins et al. 1997). However, areas left untreated become increasingly non-productive for livestock and wildlife forage.

We evaluated an alternative strategy to achieve multiple-use goals: aerial spraying thickets of mature, multi-stemmed mesquite with clopyralid alone at $0.28 \mathrm{~kg}$ $\mathrm{ha}^{-1}$. This treatment achieves moderate root-kill (30-50\%) (Jacoby et al. 1991, Bovey and Whisenant 1991), but there is no quantitative information available regarding foliage responses of surviving plants. We have observed that most surviving plants have a ragged appearance called "stem flagging" in which portions of the tree canopies survive (Jacoby and Ansley 1991, Ansley et al. 1996). Stemflagged mesquite often have little or no basal regrowth, yet canopy foliage is reduced substantially. The reduced foliage, coupled with few or no basal sprouts, shifts the physiognomy of multistemmed mesquite to an arborescent "savanna" appearance, similar to that of few- or single-stemmed mesquite that have never experienced a top-killing disturbance. Use of clopyralid at $0.28 \mathrm{~kg} \mathrm{ha}^{-1}$ may enhance multiple-use goals by reducing the competitive ability of mesquite and, thereby, increasing forage production for livestock and wildlife, yet leaving adequate foliage for wildlife cover. In addition, apical dominance exerted by stemflagged mesquite may limit multistemmed basal regrowth and thus extend treatment effects.

The first objective of this study was to evaluate the potential of aerial sprays of clopyralid at $0.28 \mathrm{~kg} \mathrm{ha}^{-1}$ to convert mesquite thickets to savannas by reducing mesquite foliage amount to an intermediate level (by $50-70 \%$ ), yet preserving apical dominance and limiting basal sprouting. We compared responses in this treatment to those in an untreated control and to aerial sprays of clopyralid + triclopyr at $0.28+0.28 \mathrm{~kg} \mathrm{ha}^{-1}$. Our hypothesis was that the clopyralid treatment would reduce mesquite foliage amount by at least $50 \%$ and maintain apical dominance in surviving trees to a greater degree than would the clopyralid+triclopyr treatment. A second objective was to determine amount of foliage in partially top-killed (i.e., "stemflagged") plants needed to maintain apical dominance. Apical dominance was maintained in multi-stemmed mesquite partially top-killed by fire if $40 \%$ of foliage remained intact (Ansley et al. 1997b, Ansley and Jacoby 1998). We hypothesized that this relationship would be the same in mesquite partially top-killed by clopyralid.

\section{Study Sites}

Research was conducted on 2 private ranches in the northern Rolling Plains ecological area of Texas: Kite Trap on the Waggoner Ranch south of Vernon $\left(33^{\circ} 53\right.$ 'N, $99^{\circ} 02^{\prime} \mathrm{W}$; elev. $352 \mathrm{~m}$ ), and Windmill pasture on the $\mathrm{Y}$ Ranch west of Crowell ( $33^{\circ} 54^{\prime} \mathrm{N}, 100^{\circ} 03^{\prime} \mathrm{W}$; elev. $488 \mathrm{~m}$ ). The sites are $80 \mathrm{~km}$ apart and differ in herbaceous species composition and soils. Kite Trap has an equal mixture of cool- and warm-season grasses, while Windmill pasture is dominated by warm-season grasses Primary cool-season grass species at Kite Trap are perennial Texas wintergrass (Nassella leucotricha Trin. and Rupr.) and the annual, Japanese brome (Bromus japonicus Thunb ex. Murray). Primary warm-season grasses are buffalograss (Buchloe dactyloides [Nutt.] Engelm.), meadow dropseed (Sporobolus asper [Michx.] Kunth var. drummondii [Trin.] Vasey), silver bluestem (Bothroichloa laguroides [DC.] Herter. Subspp torreyana [Steud.]), and sideoats grama (Bouteloua curtipendula [Michx.] Torr.). Primary grass species at Windmill pasture are buffalograss, sideoats grama, and tobosagrass (Hilaria mutica [Buckl.] Benth), with lesser amounts of Texas wintergrass and Japanese brome.

Mean annual rainfall at Kite Trap is 653 $\mathrm{mm}$. Soils are fine, mixed, thermic Typic Paleustolls of the Tillman series which are alluvial clay loams from the surface to 3-4 $m$ depth, underlain by Permian sandstone/shale parent material (Koos et al. 1962). Mean annual rainfall at Windmill pasture is $630 \mathrm{~mm}$. Soils are fine-silty, mixed, thermic Typic Calciustolls of the Quanah series, and fine, montmorillonitic, thermic Typic Haplusterts of the Hollister series (NRCS-Vernon, pers. comm). Soils at Windmill pasture are not as deep as those at Kite Trap and are underlain by calcareous limestone or gypsum rock.

Both sites were dominated by multistemmed, regrowth mesquite due to previous top-killing treatments. Mean tree height was $2.4 \mathrm{~m}( \pm 0.3)$ at Kite Trap and $2.2 \mathrm{~m}( \pm 0.1)$ at Windmill pasture. Mean number of basal stems tree ${ }^{-1}$ was $5.7( \pm$ $0.6)$ at Kite Trap and $6.3( \pm 0.6)$ at Windmill pasture. Less than $20 \%$ of trees had $>10$ basal stems tree ${ }^{-1}$, and $38 \%$ of the mesquite at each site were classified as few-stemmed (1-3 basal stems tree ${ }^{-1}$ ), possibly due to ongoing recruitment of new plants after treatment. Basal stem diameter ranged from $5-10 \mathrm{~cm}$ at both sites. Livestock grazing was continuous at moderate stocking rate at Windmill pasture and sporadic with variable stocking rates for short intervals at Kite Trap.

\section{Materials and Methods}

Herbicide plots were established at Windmill pasture on 08 July 94, and at Kite Trap on 02 July 96 using fixed-wing aircraft (Hardcastle Ag-Air, Inc., Vernon, Tex.). Treatments were (1) untreated, (2) clopyralid alone at $0.28 \mathrm{~kg} \mathrm{ha}^{-1}$ (clopyralid), and (3) clopyralid + triclopyr at $0.28+0.28 \mathrm{~kg} \mathrm{ha}^{-1}$ (clopyralid+triclopyr), arranged in a randomized complete block design at each location with 4 replications per treatment. Plot size at Windmill pasture was $120 \mathrm{~m}$ x $610 \mathrm{~m}$ (7.2 ha) with 6 spray swaths per plot (each swath $20 \mathrm{~m}$ ). Plot size at Kite Trap was $100 \mathrm{~m}$ x $366 \mathrm{~m}$ (3.6 ha) with 5 swaths per plot. Herbicide 
treatments were applied in 37.4 liters total volume $\mathrm{ha}^{-1}$ (4 gallons acre $\left.{ }^{-1}\right)$ in a $1: 7$ diesel fuel-to-water emulsion (4.7 liters of diesel ha $\left.{ }^{-1}\right)$. At Windmill pasture, herbicide treatments were applied between 0800 and 1000 hours with air temperatures $22-27^{\circ} \mathrm{C}$, wind speed $11-16 \mathrm{~km}$ hour $^{-1}$ and soil temperature $27^{\circ} \mathrm{C}$ at $46 \mathrm{~cm}$ depth. At Kite Trap treatments were applied between 0700 and 900 hours with air temperatures $25-31^{\circ} \mathrm{C}$, wind speed $3-11 \mathrm{~km}$ hour $^{-1}$, and soil temperature $29^{\circ} \mathrm{C}$ at 46 $\mathrm{cm}$ depth. Mesquite foliage conditions at both sites were rated as good to excellent. Soil moisture conditions were dry at Kite Trap. A 3.9-cm rain occurred 2 days prior to spraying and a $3.0 \mathrm{~cm}$ rain occurred 1 day after spraying at Windmill pasture.

In 2001, at 5 and 7 years post-treatment at Kite Trap and Windmill pastures, respectively, 60 randomly selected mesquite trees were evaluated in each plot to determine foliage responses at both the stand- and tree-level. Stand-level response variables included: percent of trees with complete above-ground mortality that had basal regrowth (top-kill), percent of trees with foliage on original stems only and no basal regrowth (SF-only), percent of trees with stem foliage and basal regrowth (SFBR), percent of trees with complete mortality (root-kill), percent aerial cover, vertical distribution of foliage with respect to original woody canopies, and percent of the total population (live+dead trees) and of live-only trees that maintained apical dominance. Tree-level response variables included percent foliage reduction per tree, foliage height, live canopy area (determined by measuring foliage radius (r) in 2 perpendicular directions, averaging the 2 values and calculating area by $\pi r^{2}$ ) and height of basal regrowth. Foliage reduction per tree was a visual estimate of the amount of foliage present at 5-7 years after spraying as a percentage of foliage estimated to be present before spraying (based on the spatial distribution of the original woody canopy). Height of basal regrowth was measured in the 2 herbicide treatments only.

Mesquite aerial cover was determined using the line intercept method in spring 2001 (Canfield 1941). Canopy intercept was measured along three, $60-\mathrm{m}$ line transects in each plot. In addition, pre-treatment mesquite cover was determined from color-infrared aerial images of each site taken 1 year prior to treatment (field data were not available). Images were scanned and geo-referenced in Arcview GIS (Ansley et al. 2001), and cover was determined using a variation of the line inter- cept method. Five computer-generated lines (each scaled to $60 \mathrm{~m}$ length on the images) were established in each plot at approximately the same position as where the field data were obtained. Intercept was measured manually along each line using the distance measure feature in Arcview. To compare the accuracy of field-determined and image-determined cover, computer generated transects were located on aerial images of Kite Trap taken in September 2000 in each of the 12 plots where line-intercept was field-measured in 2001 (assuming cover had not changed significantly from 2000 to 2001). These data were closely related $\left(r^{2}=0.94 ; y=\right.$ $0.97 \mathrm{x}-0.98 ; \mathrm{n}=12$ ). Post-treatment aerial images were not available for Windmill pasture.

Vertical distribution of foliage within mesquite canopies was determined at the stand level by visually dividing the original woody canopy of each tree into 3 equal horizontal layers (upper, middle and lower) and noting whether foliage was present or absent in each layer. Basal sprouting, if present, was assigned to the lower layer. Percent of trees having foliage in each canopy "layer" was then determined.

Mesquite apical dominance was estimated by establishing a level of basal regrowth above which it was assumed apical dominance was lost. During evaluations, it was noticed that many trees in untreated plots had a few basal sprouts (usually $<3$ ), yet these trees were obviously allocating most of their resources to growth of apical tissue. In addition, nearly all trees that were completely top-killed in the treated plots had numerous $(>5)$ basal sprouts. Therefore, to identify apical/basal dominance trends in partially top-killed trees, we defined trees with 5 or more basal sprouts as having "many" sprouts. A tree with "many" sprouts was assumed to have lost apical dominance in favor of basal regrowth. Trees without "many" sprouts were assumed to have maintained apical dominance.

\section{Statistical Analysis}

All mesquite response variables were analyzed using a split-plot analysis of variance with site as the whole plot and herbicide treatment as the subplot (4 replicates per treatment at each site). We used the replicate by site mean square as the error term to test for effects of site, and the pooled error to test for treatment effect and site by treatment interaction (SAS 1987). If a site by treatment interaction was significant, differences between treatments were analyzed within each site (Freund and Russell 1981). Means were compared using LSD $(\mathrm{P} \leq 0.05)$. Percentage data were subjected to arcsin transformation prior to analysis.

\section{Results}

\section{Mesquite Stand-level Responses}

Analysis indicated a significant $(\mathrm{P} \leq$ 0.05 ) main effect of treatment for 12 of the 14 post-treatment response variables evaluated (Table 1). Effect of site was significant for 2 variables, percent top-kill and percent of trees with foliage in the upper

Table 1. Effect of treatment and site as sources of variation on variables measured at the stand and individual tree levels. $P$ values are shown where effects are significant $(P \leq 0.05$; ns $=$ not significant).

\begin{tabular}{|c|c|c|c|}
\hline Variable & Trt & Site & $\begin{array}{l}\text { Trt } x \\
\text { Site }\end{array}$ \\
\hline \multicolumn{4}{|l|}{ Stand Level } \\
\hline Trees with basal sprouts only (top-kill) (\%) & 0001 & .0389 & ns \\
\hline Trees with stem foliage only (SF-only) (\%) & .0001 & ns & ns \\
\hline Trees with stem foliage and basal sprouts (SFBR) (\%) & ns & ns & ns \\
\hline Trees root-killed (root-kill) $(\%)$ & .0001 & ns & .0065 \\
\hline Mesquite cover, pre-treatment (\%) & ns & ns & ns \\
\hline Mesquite cover, post-treatment $(\%)$ & .0001 & ns & ns \\
\hline Live trees with foliage in upper canopy layer (\%) & .0001 & .0355 & ns \\
\hline Live trees with foliage in middle canopy layer $(\%)$ & .0001 & ns & ns \\
\hline Live trees with foliage in lower canopy layer $(\%)$ & .0006 & ns & ns \\
\hline$\%$ of total population (live+dead) with "many" basal sprouts & .0001 & ns & ns \\
\hline$\%$ of live-only trees with "many" basal sprouts & .0001 & ns & ns \\
\hline \multicolumn{4}{|l|}{ Tree Level } \\
\hline Foliage reduction per tree $(\%)$ & .0001 & ns & .0493 \\
\hline Foliage height $(\mathrm{m})$ & .0001 & ns & ns \\
\hline Live canopy area per tree $\left(\mathrm{m}^{2}\right)$ & .0001 & ns & ns \\
\hline Height of basal regrowth (m) & ns & ns & ns \\
\hline
\end{tabular}


Table 2. Mesquite percent top-kill, stem foliage only (SF-only) trees and stem foliage+basal regrowth (SFBR) trees in response to herbicide treatments, 2001 (Kite Camp and Windmill sites pooled). Values in parentheses are 1 standard error $(n=8 ; 4$ reps $x 2$ sites). Means with similar letters are not significantly different $(P \leq \mathbf{0 . 0 5})$.

\begin{tabular}{|c|c|c|c|c|}
\hline Treatment & Rate & Top-kill & SF-Only & SFBR \\
\hline & $\left(\mathrm{kg} \mathrm{ha}^{-1}\right)-$ & $\ldots \ldots$ & $--(\%) \ldots$ & $\ldots \ldots$ \\
\hline Untreated & - & $0(0) \mathrm{c}$ & $87.5(4.1) \mathrm{a}$ & $12.5(4.1) \mathrm{a}$ \\
\hline Clopyralid & 0.28 & $17.1(2.2) \mathrm{b}$ & $51.7(6.4) b$ & $9.4(1.8) \mathrm{a}$ \\
\hline Clopyralid + Triclopyr & $0.28+0.28$ & $35.8(3.6) \mathrm{a}$ & $5.8(1.8) \mathrm{c}$ & $4.0(0.7) \mathrm{a}$ \\
\hline
\end{tabular}

canopy layer. There was a significant site by treatment interaction for percent rootkill and percent foliage reduction per tree.

Percent top-kill was twice as high in the clopyralid+triclopyr treatment than the clopyralid treatment (Table 2), and was greater at Kite Trap $(20 \%)$ than Windmill $(15 \%)$ (Table 1). Percent of trees with stem foliage only and no basal sprouts (SF-only) was over 8 times greater in the clopyralid than the clopyralid+triclopyr treatment (52 vs. 6\%) (Table 2). Percent
Pre-treatment mesquite cover ranged from 44 to $50 \%$ across all treatments (Table 4). Cover increased in the untreated plots by an average of 6 percentage units from 1993 (Windmill) or 1995 (Kite Trap) to 2001 , an average of about 0.8 to 1 percentage unit year ${ }^{-1}$. Mesquite cover in 2001 was slightly over half that of pretreatment cover ( 23 vs. $44 \%$ ) in the clopyralid treatment and $1 / 5$ th pre-treatment cover in the clopyralid+triclopyr treatment (10 vs. $50 \%$ ). The clopyralid treatment

Table 3. Mesquite percent root-kill and foliage reduction per tree in response to herbicide treatments on 2 sites, 2001. Values in parentheses are 1 standard error $(n=4)$. Means with similar letters within a column and site are not significantly different $(P \leq 0.05)$.

\begin{tabular}{|c|c|c|c|c|}
\hline Site & Treatment & Rate & Root-kill & $\begin{array}{l}\text { Foliage } \\
\text { Reduction } \\
\text { Per Tree }\end{array}$ \\
\hline \multirow{4}{*}{ Kite Trap } & & $\left(\mathrm{kg} \mathrm{ha}^{-1}\right)-$ & $\ldots \ldots$ & - . - . \\
\hline & Untreated & - & $0(0) \mathrm{b}$ & $5.3(1.4) \mathrm{c}$ \\
\hline & Clopyralid & 0.28 & $33.8(7.8) \mathrm{a}$ & $74.4(7.0) \mathrm{b}$ \\
\hline & Clopyralid + Triclopyr & $0.28+0.28$ & $52.1(4.5) \mathrm{a}$ & $98.2(0.7) \mathrm{a}$ \\
\hline \multirow[t]{3}{*}{ Windmill } & Untreated & - & $0(0) \mathrm{c}$ & $8.8(2.8) \mathrm{c}$ \\
\hline & Clopyralid & 0.28 & $10.0(1.8) b$ & $58.8(1.9) \mathrm{b}$ \\
\hline & Clopyralid + Triclopyr & $0.28+0.28$ & $56.7(5.8) \mathrm{a}$ & $96.4(1.5) \mathrm{a}$ \\
\hline
\end{tabular}

of trees having stem foliage and basal regrowth (SFBR) did not differ among treatments. Root-kill was similar for the 2 herbicide treatments at Kite Trap, but was different at Windmill pasture (Table 3), explaining the site by treatment interaction. Root-kill was over $52 \%$ in the clopyralid+triclopyr treatment at both sites. Root-kill in the clopyralid treatment was greater at Kite Trap (34\%) than at Windmill $(10 \%)$.

Table 4. Pre- and post-treatment mesquite canopy cover in response to treatments (Kite Camp and Windmill sites pooled). Values in parentheses are 1 standard error $(n=8 ; 4$ reps $x 2$ sites). Means with similar letters within a column are not significantly different $(P \leq 0.05)$.

\begin{tabular}{|c|c|c|c|}
\hline Treatment & Rate & $\begin{array}{l}\text { Pre-treatment } \\
\text { Cover }\end{array}$ & $\begin{array}{l}\text { Post-treatment } \\
\text { Cover }\end{array}$ \\
\hline & $\left(\mathrm{kg} \mathrm{ha}^{-1}\right)-$ & -....... & $\ldots \ldots$ \\
\hline Untreated & - & $48.2(5.1) \mathrm{a}$ & $53.9(4.9) \mathrm{a}$ \\
\hline Clopyralid & 0.28 & $43.8(3.5) \mathrm{a}$ & $23.2(2.0) \mathrm{b}$ \\
\hline Clopyralid + Triclopyr & $0.28+0.28$ & $50.4(4.0) \mathrm{a}$ & $9.5(1.5) \mathrm{c}$ \\
\hline
\end{tabular}

layer in almost one-third of the trees (Table 5). About $70 \%$ of live trees in the clopyralid treatment had foliage in upper and middle canopy layers, while only 12 and $18 \%$ of live trees in the clopyralid+triclopyr treatment had foliage in the upper and middle layers, respectively. A greater percentage of live trees in the clopyralid+triclopyr treatment had foliage in the lower canopy layer than occurred in the other 2 treatments. The significant site effect (Table 1) occurred in the upper layer only. A greater percentage of trees at Windmill pasture $(66 \%)$ than at Kite Trap $(55 \%)$ had foliage present in this layer.

\section{Mesquite Tree-level Responses}

Foliage reduction per tree was $>96 \%$ in the clopyralid+triclopyr and $>58 \%$ in the clopyralid treatment at both sites (Table $3)$. Differences between the 2 herbicide treatments were greater at Windmill pasture than at Kite Trap, possibly explaining the site by treatment interaction that was just significant $(P=0.049)$ (Table 1). Live foliage height and canopy area were significantly reduced by both herbicide treatments, but to the greatest extent by the clopyralid+triclopyr treatment (Table 6). Basal regrowth height was not different between the 2 herbicide treatments and averaged $0.9 \mathrm{~m}$ after 5 (Kite Trap) or 7 (Windmill) years post-treatment.

\section{Basal Sprouts and Apical Dominance (Objective 2)}

Percent of the total population of trees (live + dead) with "many" ( $\geq 5)$ basal sprouts was slightly greater in the clopyralid+triclopyr treatment than the clopyralid treatment (Table 7). However, percent of live plants with many basal sprouts was considerably greater in the clopyralid+triclopyr than the clopyralid treatment. The reciprocals $(100 \%-\%$ with many basal sprouts) of these data suggest that apical dominance was maintained in 73 and $37 \%$ of surviving trees in the clopyralid and clopyralid+triclopyr treatments, respectively. None of the untreated trees had "many" basal sprouts, but about $13 \%$ had "few" basal sprouts (the SFBR plants in Table 2).

Partially top-killed trees from the clopyralid treatment were used to determine the amount of foliage needed on original woody canopies to maintain apical dominance. At both sites, over $70 \%$ of trees (y axis) that had $>20 \%$ of foliage remaining on the original woody canopy structure maintained apical dominance (Fig. 1). As foliage remaining decreased below $20 \%$, responses differed among the 2 sites in 
Table 5. Vertical distribution of foliage on surviving mesquite in each treatment (Kite Camp and Windmill sites pooled). Values in parentheses are 1 standard error $(n=8 ; 4$ reps $x 2$ sites). Means with similar letters within each group are not significantly different $(P \leq 0.05)$.

\begin{tabular}{|c|c|c|c|c|}
\hline Treatment & Rate & $\begin{array}{l}\text { Trees with } \\
\text { Foliage } \\
\text { in Upper } \\
\text { Layer }\end{array}$ & $\begin{array}{c}\text { Trees with } \\
\text { Foliage } \\
\text { in Middle } \\
\text { Layer }\end{array}$ & $\begin{array}{l}\text { Trees with } \\
\text { Foliage } \\
\text { in Lower } \\
\text { Layer }\end{array}$ \\
\hline & $\left(\mathrm{kg} \mathrm{ha}^{-1}\right)-$ & $\ldots-\ldots$ & $--(\%)-\cdots$ & $\ldots \ldots$ \\
\hline Untreated & - & $100.0(0) \mathrm{a}$ & 97.5 (1.6) a & $68.8(5.5) b$ \\
\hline Clopyralid & 0.28 & $69.3(6.7) \mathrm{b}$ & $72.8(5.0) \mathrm{b}$ & $82.5(2.3) b$ \\
\hline Clopyralid + Triclopyr & $0.28+0.28$ & $12.0(3.0) \mathrm{c}$ & $18.1(3.2) \mathrm{c}$ & $97.0(1.8) \mathrm{a}$ \\
\hline
\end{tabular}

Table 6. Individual mesquite tree responses to herbicide treatments when evaluated in 2001 (Kite Camp and Windmill sites pooled). Values in parentheses are 1 standard error $(n=8 ; 4$ reps $x 2$ sites). Means within a column with similar letters are not significantly different $(P \leq 0.05)$.

\begin{tabular}{lcccc}
\hline \hline & & Live & Basal \\
Treatment & Rate & $\begin{array}{c}\text { Foliage } \\
\text { Height }\end{array}$ & $\begin{array}{c}\text { Canopy } \\
\text { Area }\end{array}$ & $\begin{array}{c}\text { Regrowth } \\
\text { Height }\end{array}$ \\
\hline Untreated & $\left(\mathrm{kg} \mathrm{ha}^{-1}\right)$ & $(\mathrm{m})$ & $\left(\mathrm{m}^{2}\right)$ & $(\mathrm{m})$ \\
Clopyralid & - & $2.9(0.1) \mathrm{a}$ & $47.7(3.9) \mathrm{a}$ & - \\
Clopyralid + Triclopyr & $0.28+0.28$ & $1.2(0.1) \mathrm{c}$ & $17.6(1.9) \mathrm{b}$ & $0.89(0.05) \mathrm{a}$ \\
\hline
\end{tabular}

that a greater percentage of trees at Kite Trap maintained apical dominance.

\section{Discussion}

\section{Use of Clopyralid for Savanna Development (Objective 1)}

For the purposes of mesquite savanna development from multi-stemmed thickets, clopyralid at $0.28 \mathrm{~kg} \mathrm{ha}^{-1}$ achieved the targeted "intermediate" response with respect to overall foliage reduction with $>58 \%$ foliage reduction per tree (Table 3 ), $57 \%$ reduction in cover (Table 4 ), and $63 \%$ reduction of canopy area of individual plants (Table 6). Apical dominance was maintained in $73 \%$ of surviving plants (Table 7). As expected, the clopyralid+triclopyr treatment killed more mesquite plants and caused greater foliage reduction than the clopyralid treatment and also triggered most surviving plants into a basal regrowth mode. We thus fail to reject our first hypothesis that the clopyralid treatment would reduce mesquite foliage amount by at least $50 \%$, but would maintain apical dominance in most surviving trees to a greater degree than would the clopyralid+triclopyr treatment.

The lower root-kill in the clopyralid treatment at Windmill pasture than at Kite Trap may be explained by the inherent variability in response of mesquite to this treatment (Bovey and Whisenant 1992) and/or by the rainfall events that occurred both prior to and following spraying at should be noted that rainfall did not reduce root-kill in the clopyralid+triclopyr treatment.

The literature indicates a fairly consistent range of mesquite root-kill responses to the $0.28 \mathrm{~kg} \mathrm{ha}^{-1}$ rate of clopyralid with one notable exception. Jacoby et al. (1991) found a range of $29-52 \%$ root-kill, Bovey and Meyer (1985) reported 37\%, and Bovey and Whisenant (1991) reported $33 \%$ root-kill. The exception was a study by Bovey and Whisenant (1992), who found root-kills of 0 and $93 \%$ in 2 consecutive years with this clopyralid rate. Further tests are needed to determine factors that affect root-kill using this rate. In addition, other higher rates should be tested, although a rate of $0.56 \mathrm{~kg} \mathrm{ha}^{-1}$ clopyralid has been found to yield results similar to the $0.28 \mathrm{~kg} \mathrm{ha}^{-1}$ clopyralid $+0.28 \mathrm{~kg}$ $\mathrm{ha}^{-1}$ triclopyr treatment (Jacoby et al. 1991, Bovey and Whisenant 1991, 1992) and may remove too much foliage from the landscape for wildlife screening cover.

Root-kill, while certainly important, may not be the most important variable with respect to savanna development. Reduction of the overall foliage amount is probably more critical and that was achieved at both sites. In addition, it is important to note that evaluations were conducted 5-7 years after treatment, indicating that the foliage reduction effects had reasonable longevity.

\section{Stem Flagging and Apical Dominance (Objective 2)}

The minimum of $20 \%$ of original canopy foliage required to maintain apical dominance in partially top-killed trees in the clopyralid treatment was lower than the $40 \%$ required by mesquite that had been partially top-killed by low-intensity fires (Ansley et al. 1997b, Ansley and Jacoby 1998) (Fig. 1). Thus, we reject our hypothesis that $40 \%$ of original foliage is needed to maintain apical dominance.

Differences in responses between fireand clopyralid-mediated apical dominance may reflect differences between physical

Table 7. Percent of total population (live +dead) and of live trees only that had "many" ( $\geq 5$ ) basal sprouts in response to herbicide treatments when evaluated in 2001 (Kite Camp and Windmill sites pooled). Values in parentheses are 1 standard error $(n=8 ; 4$ reps $x 2$ sites). Means with similar letters within a column are not significantly different $(P \leq 0.05)$.

\begin{tabular}{lccc}
\hline \hline Treatment & Rate & $\begin{array}{c}\text { Total Pop. } \\
\text { with "Many" } \\
\text { Basal Sprouts }\end{array}$ & $\begin{array}{c}\text { Live Trees } \\
\text { with "Many" } \\
\text { Basal Sprouts }\end{array}$ \\
\hline Untreated & $\left(\mathrm{kg} \mathrm{ha}^{-1}\right)$ & $(\%)$ & $(\%)$ \\
Clopyralid & - & $0(0) \mathrm{c}$ & $0(0) \mathrm{c}$ \\
Clopyralid + Triclopyr & 0.28 & $20.8(1.8) \mathrm{b}$ & $27.4(3.1) \mathrm{b}$ \\
\hline
\end{tabular}




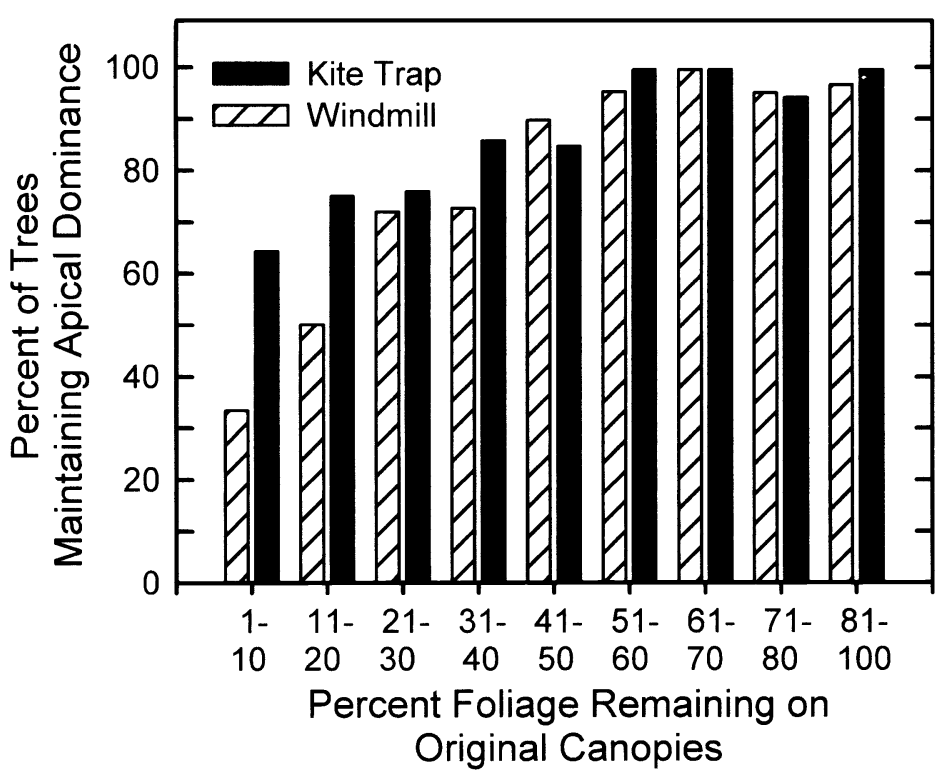

Fig. 1. The percent of trees maintaining apical dominance ( $y$ axis) as a function of amount of foliage remaining on original woody canopies 5-7 years after being partially top-killed by aerial sprays of clopyralid at $0.28 \mathrm{~kg} \mathrm{ha}^{-1}$ at Kite Trap and Windmill pastures. Number of plants evaluated in each $x$ axis group ranged from 20 to 30 .

effects of fire and physiological effects of clopyralid. Most subterranean meristem that produces basal regrowth is protected from fire effects by the soil (Ansley and Jacoby 1998). Additionally, few main support stems with rough bark are killed by fire because of the protective bark layer. Because heat is generated from beneath mesquite canopies as herbaceous fuel burns, growing points on small branches and twigs in middle and lower canopy regions are killed but nearly all main support stems retain foliage in upper portions of the canopy (Fig. 2). The resulting relationship between percent foliage remaining per tree following fire and degree of basal sprouting follows a reverse sigmoidal curve. When remaining foliage is less than $30 \%$ of pre-burn levels, nearly all the trees produce "many" basal sprouts. When foliage remaining exceeds $40 \%$, sprouting is almost completely eliminated (Ansley et al. 1997b).

In contrast to the response to low-intensity fires, stem-flagging from clopyralid occurred throughout the vertical length of the canopy. Most stem-flagged trees had a combination of partially defoliated stems and other stems that were completely killed (Figs. 2 and 3). Most dead stems had no evidence of sprouting at the stem base, suggesting that clopyralid was translocated to stem bases and killed the meristematic tissue (Bovey et al. 1986, Meyer and Bovey 1986). By killing some support stems and associated basal meristems, the clopyralid treatment eliminated the potential for resprouting from that portion of the base of the tree. If the remaining live stems retained enough foliage to measured. maintain apical dominance at each of their respective stem bases, this would produce the appearance that very little foliage in the original woody canopy was needed to maintain apical dominance for the entire tree. Indeed, many clopyralid-treated plants with less than $20 \%$ foliage remaining per tree maintained apical dominance (Fig. 1). More trees at Kite Trap may have maintained apical dominance at $<20 \%$ foliage remaining levels than at Windmill because more support stems within a tree may have been killed at Kite Trap, although we have no data to substantiate this. Adding further support to the assumption that some support stems were killed and others survived is the observation that the clopyralid treatment reduced live canopy area to a greater degree (63\%) than it reduced foliage height $(31 \%)$ (Table 6).

The contrasting responses of partially top-killed trees in low-intensity fire and clopyralid treatments support a general hypothesis that basal sprouting is controlled within each support stem rather than at the organismal or "whole tree" level and explains why efforts to prune multi-stemmed mesquite to a fewstemmed physiognomy by mechanically removing stems results in vigorous sprouting from those stem bases (Patch et al.

1998). Further investigation into physio-

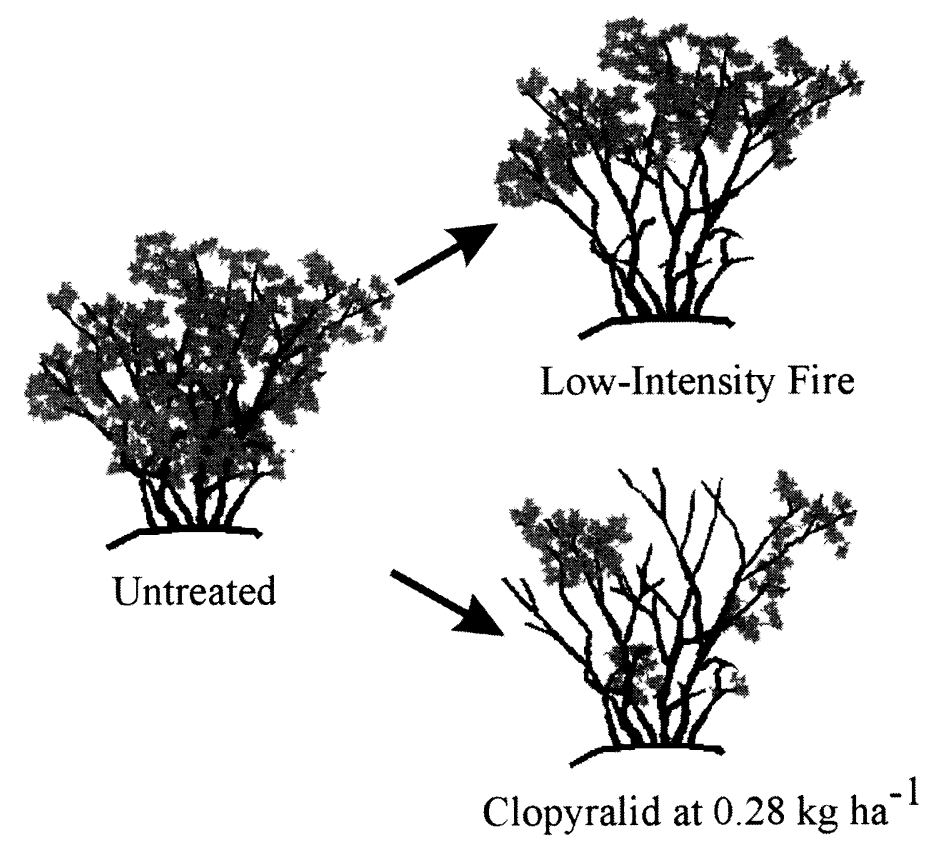

Fig. 2. Conceptual illustration of a mature, multi-stemmed mesquite tree partially top-killed by a low-intensity fire (adapted from Ansley and Jacoby 1998) or an aerial spray of clopyralid at $0.28 \mathrm{~kg} \mathrm{ha}^{-1}$. Number of basal stems depicted is similar to the mean of all trees 


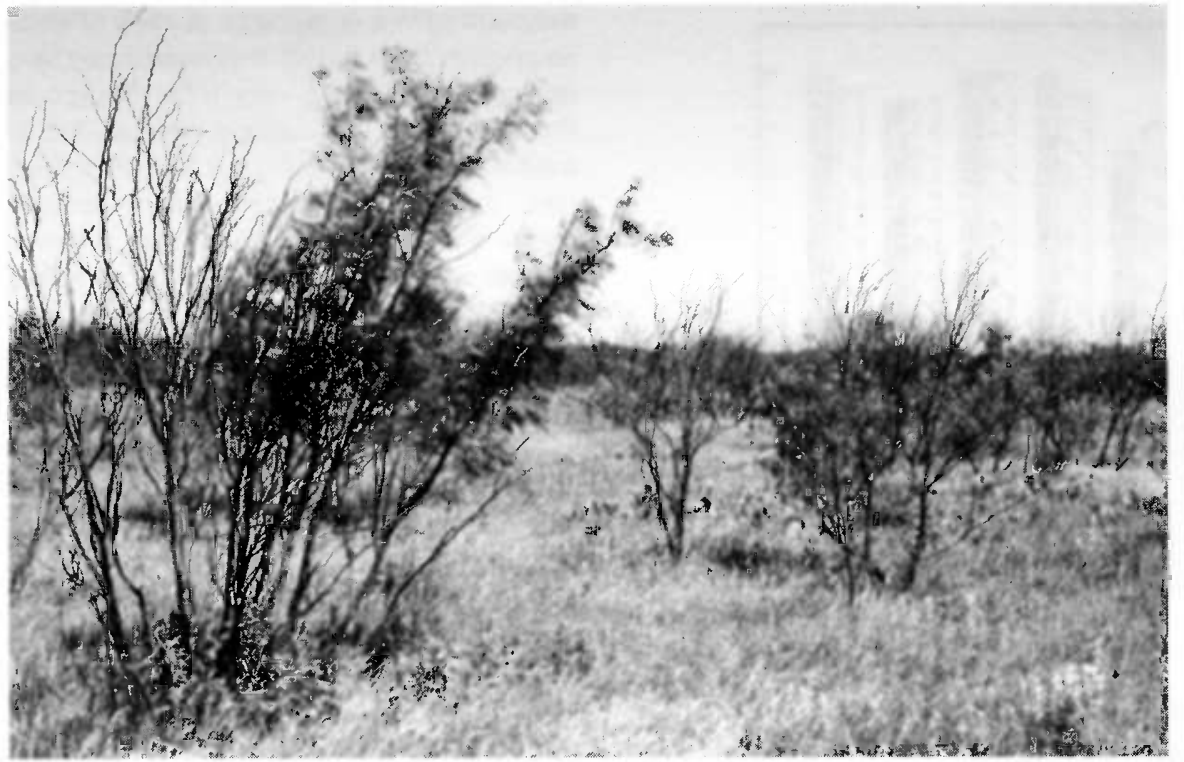

Fig. 3. Ground-level view of a mesquite plot at Kite Trap in 2000 treated with clopyralid at $0.28 \mathrm{~kg} \mathrm{ha}^{-1}$ in 1996. None of the mesquite in view have basal regrowth. Vegetation at the base of the large tree on the left is grass growth.

logical mechanisms is needed.

\section{Clopyralid+Triclopyr Mixture}

Clopyralid was initially marketed to be sprayed alone or in combination with picloram (4-amino-3,5,6- trichloro-2pyridinecarboxylic acid) for mesquite control (Bovey et al. 1981, Jacoby et al. 1981, 1990, 1991). However, after its commercial release in 1990, many livestock producers expressed dissatisfaction with these treatments because of excessive stem-flagging (Jacoby and Ansley 1991). The combination of clopyralid with triclopyr was developed as an industry response to this dissatisfaction. It is believed that the triclopyr ester provides the top-killing action in those plants not top-killed by clopyralid alone. Because the monoethanolamine salt of clopyralid has low volatility, it may not produce the vapors or small particles that increase coverage within a canopy as do ester herbicide formulations, such as triclopyr. However, laboratory tests have also found that the addition of triclopyr to clopyralid increases clopyralid deposition, absorption, and translocation in mesquite when compared to clopyralid applied alone (Bovey et al. 1988).

The $0.28 \mathrm{~kg} \mathrm{ha}^{-1}$ clopyralid $+0.28 \mathrm{~kg} \mathrm{ha}^{-1}$ triclopyr treatment was moderately successful in converting mesquite thickets to open grassland by yielding $>52 \%$ rootkill, $36 \%$ top-kill and $>96 \%$ canopy reduction (Tables 2 and 3 ). There is little field research of this treatment combination in the literature, although Bovey and
The level of root-kill produced by the clopyralid+triclopyr treatment reduced effects of basal regrowth in surviving plants when projected to the landscape level. As noted in Table 7, while the percent of surviving mesquite with many basal sprouts was much greater in the clopyralid+triclopyr than the clopyralid treatment, this percentage, when averaged over all trees (live + dead), was more similar between treatments, although it remained significantly different (29 vs. $21 \%$; Table 7 ). Recent studies suggest the clopyralid+triclopyr treatment has an effective treatment life of at least 20 years if increased herbaceous production for livestock is the management goal (McMullen 2000, Teague et al. 2001). Conversely, in the same studies, herbicide treatments that only top-killed mesquite and induced basal regrowth were not economical.

Basal regrowth rate of $0.9 \mathrm{~m}$ in 5-7 years was not nearly as rapid as that found by Hamilton et al. (1981) in south Texas after a top-killing fire, or by Scifres et al. (1974), who found in north Texas, that mesquite regrowth attained $1.6 \mathrm{~m}$ height 8 years after 2,4,5-T (2,4,5-trichlorophenoxy acetic acid) application. Our lower regrowth rates were possibly due to drought conditions that occurred during much of the period between application of the herbicide treatments in 1994 or 1996 and final evaluations in 2001 . They may also indicate that clopyralid and clopyralid+triclopyr treatments have a negative impact on the growth rate of basal regrowth.

It should be noted that this study was conducted on sites where the majority of mesquite were mature, multi-stemmed regrowth that had been top-killed by earlier treatments. As such, our results may not apply to stands dominated by undisturbed mesquite, although $38 \%$ of the trees evaluated were few-stemmed ( $1-3$ stems tree $\left.{ }^{-1}\right)$ and mean basal stems tree ${ }^{-1}$ was only 6 . Much of the mesquite in Texas has experienced a prior disturbance. This assumption is supported by survey data that indicates that about 20 million ha of Texas rangelands are infested with mesquite (NRCS 1985) and total acreage of all brush species treated in Texas from 1940-1984 was > 26 million ha (Welch 1985). While Welch's report did not specify the acreage of mesquite treated, it can be assumed that a significant portion of this total was mesquite and that most of the treatments were non-lethal and produced regrowth. Thus, we believe the pre-treatment physiognomy of mesquite in our study was typical of the majority of mature mesquite that currently exist. Research is needed to determine if similar responses occur in single-stemmed mesquite. 


\section{Management Implications}

There is much evidence to suggest that on areas with uniform soil types, mesquite savannas will transition to thickets if left unmanaged (Archer 1995, Ansley et al. 2001). This process is accelerated by a variety of factors, including distribution of mesquite seeds by livestock and the reduction of naturally occurring fires (Archer et al. 1988, Brown and Archer 1989, Kramp et al. 1998). Within this north Texas ecosystem, mesquite savanna is most likely the "transition" phase between true grassland and woodland thicket "states". There is little doubt that maintaining a site as a mesquite savanna will require periodic management inputs.

Treating mesquite thickets in strips or blocks, or thinning stands by selectively killing individual mesquite plants, are options that provide spatial discontinuity and may achieve multiple-use goals (Jacoby 1985, Scifres et al. 1985, Scifres and Koerth 1986). However, there are some problems associated with these "brush sculpting" treatments, including high cost of implementation and maintenance, especially if mechanical treatments are used (Rollins et al. 1997), or if the mesquite is allowed to thicken and mature before control is attempted. A disadvantage of leaving untreated strips is that these strips decline in productivity for livestock and wildlife grazing and hinder attempts to gather livestock and harvest wildlife. Use of low-cost maintenance treatments such as prescribed fire are often not practical because discontinuity of herbaceous fine fuel in areas supporting dense mesquite disrupt movement of the flame front (Ansley et al. 1997a).

Aerial sprays of clopyralid at $0.28 \mathrm{~kg} \mathrm{ha}^{-1}$ may facilitate conversion of mesquite thickets to savannas and enhance opportunities for multiple-use management for livestock and wildlife. This treatment maintains some screening cover for wildlife, yet surviving mesquite will have less leaf area per tree and will likely be less competitive with forage grasses than before treatment, thereby increasing forage production for livestock and wildlife (Fig. 3). In addition, most surviving mesquite will largely have elevated, rather than basal regrowth foliage that theoretically could be maintained using lowintensity fires (Ansley et al. 1996, 1997b).

Twenty years ago, the results of the low rate of clopyralid, as documented in this study, would have been perceived as an unsatisfactory control because of the stem flagging. However, societal perceptions of human manipulations of the landscape have changed and there is increasing interest in maintaining diversity and multipleuse options on rangelands (Cairns and Lackey 1992, Fulbright 1996). Effects of clopyralid at $0.28 \mathrm{~kg} \mathrm{ha}^{-1}$ alone or in combination with other "brush sculpting" treatments, such as patterned spraying or individual plant thinning, on floral and faunal diversity and forage responses for both livestock and wildlife need further investigation.

\section{Literature Cited}

Ansley, R.J., and P.W. Jacoby. 1998 . Manipulation of fire intensity to achieve mesquite management goals in north Texas. P. 195-204 In: T.L. Pruden and L.A. Brennan (eds.). Fire in Ecosystem Management: Shifting the Paradigm from Suppression to Prescription. Tall Timbers Fire Ecology Conf. Proc. No. 20, Tall Timbers Res. Sta., Tallahassee, Fla.

Ansley, R.J., J.F. Cadenhead, and B.A. Kramp. 1996. Mesquite savanna: a brush management option. The Cattleman Magazine 82:10-12 (April), Texas and Southwestern Cattle Raisers Assoc., Ft. Worth, Tex.

Ansley, R.J., B.A. Kramp, and T.L. Moore. 1997b. Development and management of mesquite savanna using low intensity prescribed fires. p. 155-161, In: J.M. Greenlee (ed), Proc: Fire Effects on Threatened and Endangered Species and Habitats Conference, 13-15 Nov. 1995, Coeur d'Alene, Ida, Int. Assoc. Wildland Fire, Fairfield, Wash.

Ansley, R.J., X.B. Wu, and B.A. Kramp. 2001. Observation: long-term increases in mesquite canopy cover in a north Texas savanna. J. Range Manage. 54:171-176.

Ansley, R.J., B.A. Kramp, J.A. Huddle, and T.R. Tunnell. 1997a. Using fire for sculpting brush. p. 99-108 In: D. Rollins, D.N. Ueckert and C.G. Brown (eds.). Proc: Brush Sculptors Symposium, Sept. 17-18, 1997 Abilene, Texas. Texas Agr. Exp. Sta., San Angelo, Tex.

Archer, S. 1995. Tree-grass dynamics in a Prosopis-thornscrub savanna parkland: reconstructing the past and predicting the future. EcoScience 2:83-89.

Archer, S., C. Scifres, C.R. Bassham, and R. Maggio. 1988. Autogenic succession in a subtropical savanna: conversion of grassland to thorn woodland. Ecol. Monogr. 58:111-127

Bedunah, D.J. and R.E. Sosebee. 1984. Forage response of a mesquite-buffalograss community following range rehabilitation. $\mathrm{J}$. Range Manage. 37:483-487.

Bovey, R.W. and R.E. Meyer. 1985. Herbicide mixtures for control of honey mesquite (Prosopis glandulosa). Weed Sci 33:349-352.
Bovey, R.W. and S.G. Whisenant. 1991 Control of honey mesquite with clopyralid, triclopyr, or clopyralid:triclopyr mixtures. J. Range Manage. 44:52-55.

Bovey, R.W. and S.G. Whisenant. 1992 Honey mesquite (Prosopis glandulosa) control by synergistic action of clopyralid: triclopyr mixtures. Weed Sci. 40:563-567.

Bovey, R.W., H. Hein, Jr., and R.E. Meyer. 1986. Concentration of 2,4,5-T, triclopyr, picloram and clopyralid in honey mesquite (Prosopis glandulosa) stems. Weed Sci. 34: 211-217.

Bovey, R.W., H. Hein, Jr., and R.E. Meyer. 1988. Phytotoxicity and uptake of clopyralid in honey mesquite (Prosopis glandulosa) as affected by adjuvants and other herbicides. Weed Sci. 36: 20-23.

Bovey, R.W., R.E. Meyer, and J.R. Baur 1981. Potential herbicides for brush control. J. Range Manage. 34:144-148.

Brown, J. R. and S. Archer. 1989. Woody plant invasion of grasslands: establishment of mesquite (Prosopis glandulosa var. glandulosa) on sites differing in herbaceous biomass and grazing history. Oecologia 80:19-26.

Cairns, M.A. and R.T. Lackey. 1992 Biodiversity and management of natural resources: the issues. Fisheries 17:6-10.

Canfield, R.H. 1941. Application of line interception in sampling range vegetation. $\mathrm{J}$. Forest. 39:388-394

Dahl, B.E. and R.E. Sosebee. 1984. Timingthe key to herbicidal control of mesquite. Range and Wildlife Manage. Note 2, Texas Tech Univ., Lubbock, Tex.

Dahl, B.E., R.E. Sosebee, J.P. Goen, and C.S. Brumley. 1978. Will mesquite control with 2,4,5-T enhance grass production? J. Range Manage. 31:129-131.

Fisher, C.E., C.H. Meadors, R. Behrens, E.D. Robinson, P.T. Marion, and H.L. Morton. 1959. Control of mesquite on grazing lands. Texas Agr. Exp. Sta. Bull. 935, College Station, Tex.

Freund, R.J. and R.C. Russell. 1981. SAS for linear models - a guide to the ANOVA and GLM procedures. SAS Institute, Inc., Cary, N.C.

Fulbright, T.E. 1996. Viewpoint: a theoretical basis for planning woody plant control to maintain species diversity. J. Range Manage. 49:554-559.

Fulbright, T.E. 1997. Designing shrubland landscapes to optimize habitat for whitetailed deer. p. 61-67, In: D. Rollins, D.N. Ueckert, and C.G. Brown (eds.). Proc: Brush Sculptors Symposium. Texas Agr. Exp. Sta., San Angelo, Tex.

Hamilton, W.T., L.M. Kitchen, and C.J. Scifres. 1981. Height replacement of selected woody plants following burning or shredding. Texas Agr. Exp. Sta. Bull. 1361.

Jacoby, P.W. 1985. Restoring mesquite savanna in western Texas, USA through brush and cacti management. p. 223-228. In: J.C. Tothill and J.J. Mott (eds), Ecology and Management of the World's Savannas. Australian Acad. Sci., Canberra, ACT 2601. 
Jacoby, P.W. and R. J. Ansley. 1991 Mesquite: classification, distribution, ecology, and control. Ch. 36, p. 364-376. In: L.F James, J.O. Evans, M.H. Ralphs, D.R. Child (eds), Noxious Range Weeds. Westview Press, Boulder, Colo.

Jacoby P.W., R.J. Ansley, and C.H. Meadors. 1991. Late season control of honey mesquite with clopyralid. J. Range Manage. 44: 56-58.

Jacoby P.W., C.H. Meadors, and M.A. Foster. 1981. Control of honey mesquite with 3,6-dichloropicolinic acid. Weed Sci. 29:376-378.

Jacoby P.W., R.J. Ansley, C.H. Meadors, and C.J. Cuomo. 1990. Control of honey mesquite with herbicides: influence of stem number. J. Range Manage. 43:36-38.

Koos, W. M., J. C. Williams, and M. L. Dixon. 1962. Soil survey of Wilbarger County, Texas. United States Department of Agriculture, Soil Conservation Service, Soil Survey Series 1959, No. 18, Fort Worth, Tex.

Kramp, B.A., R.J. Ansley, and T.R. Tunnell. 1998. Survival of mesquite seedlings emerging from cattle and wildlife feces in a semiarid grassland. Southwest. Natur. 43:300-312.
McMullen, S. 2000. Economic assessment of forage responses to mesquite control in the Rolling Plains of north Texas. M.S. Thesis, Texas A\&M Univ., College Station, Tex.

Meyer, R.H. and R.W. Bovey. 1986. Influence of environment and stage of growth on honey mesquite (Prosopis glandulosa) response to herbicides. Weed Sci. 34: 287-299.

SCS. 1985. Texas brush inventory. USDA-SCS Misc. Publ., Temple, Tex.

Patch, N.L., D. Geesing, and P. Felker. 1998. Suppression of resprouting in pruned mesquite (Prosopis glandulosa var. glandulosa) saplings with chemical or physical barrier treatments. For. Ecol. Manage. 112:23-29.

Rollins, D., D.N. Ueckert, and C.G. Brown (eds.). 1997. Proceedings: Brush Sculptors Symposium, Sept. 17-18, 1997, Abilene, Texas. Texas Agr. Exp. Sta., San Angelo, Tex.

SAS Institute Inc. 1987. SAS user's guide: statistics, 1987 edition. SAS Institute Inc., Cary, N.C.

Scifres, C.J. and B.H. Koerth. 1986. Habitat alterations in mixed brush from variable rate herbicide patterns. Wildl. Soc. Bull. 14: 345356.
Scifres, C.J., M.M. Kothmann, and G.W. Mathis. 1974. Range site and grazing system influence regrowth after spraying honey mesquite. J. Range Manage. 27:97-100.

Scifres, C.J., W.T. Hamilton, J.R. Conner, J.W. Stuth, J.M. Inglis, T.G. Welch, G.A. Rasmussen, and R.P. Smith. 1985. Integrated brush management systems for south Texas: development and implementation. Texas Agr. Exp. Sta. Bull. 1493.

Teague, W.R., R.J. Ansley, U.P. Kreuter, W.E. Pinchak, and J.M. McGrann. 2001. Economics of managing mesquite in north Texas: a sensitivity analysis. J. Range Manage. 54:553-560.

Teague, W.R., R. Borchardt, J. Ansley, B. Pinchak, J. Cox, J. Foy, and J. McGrann. 1997. Sustainable management strategies for mesquite rangeland: the Waggoner Kite project. Rangelands 19:4-8.

Welch, T.G. 1985. Acres of Texas rangeland treated for brush and weed control. Texas Agr. Ext. Serv. Misc. Pub., College Station, Tex. 